Research Article

\title{
EVALUATION OF TOMATO VARIETIES AGAINST RESISTANCE TO FRUIT BORER (Helicoverpa armigera hub.)
}

\author{
S. Nasrin ", M.A. Mannan, M.M. Islam, S.A.K.U. Khan \\ Agrotechnology Discipline, Khulna University \\ Khulna-9208, Bangladesh
}

\begin{abstract}
Sixteen tomato varieties were evaluated against fruit borer (Helicoverpa armigera) to find out borer resistant tomato varieties. The eight varieties were collected from Bangladesh Agricultural Research Institute (BARI) and eight varieties from the farmer's field of South-west Bangladesh. This field experiment was conducted in a protected net house suitable for inoculation of the fruit borer at germplasm center of Khulna University for two years (2018 and 2019). Data were collected on fruit physical characters, and borer infestation. The genotypes BARI Tomato-18, BARI Tomato-16, Ruma-VF, Pusa Ruby and Guli had the minimum weight of infested fruit $(3.57 \%, 3.63 \%, 4.83 \%, 7.17 \%$ and $7.67 \%$, respectively ) as well as the minimum number of infested fruits (both were bellow10\%) with the minimum number of larvae of $H$. armigera $(0.23,0.28,0.27$, 0.54 and 0.60 larvae plant $^{-1}$, respectively). BARI Tomato-8, BARI Tomato- 17 and Paltola were found as more susceptible $(29.71 \%$, $26.01 \%$ and $28.95 \%$ infestation, respectively) than the others. Maximum fruit weight plant $^{-1}$ was recorded from the genotypes BARI Tomato-18, BARI Tomato-19, Surakha and Paltola (2603g, $2687 \mathrm{~g}, 2755 \mathrm{~g}$ and $2731 \mathrm{~g}$ respectively) and among these BARI Tomato-18 and Suraksa gave maximum fresh yield plant ${ }^{-1}$ (2512.77 $\mathrm{g}$ and $2476.53 \mathrm{~g}$, respectively). The fruit infestation rate was significantly and positively correlated with fruit weight loss plant ${ }^{-1}(r$ $=0.971)$, larvae plant ${ }^{-1}(r=0.789)$, fruit diameter $(r=0.567)$ and individual fruit weight $(r=0.545)$. On the other hand, the fruit shape index $(r=-0.44)$ and the number of fruit plant ${ }^{-1}(r=-0.498)$ were significant and negatively correlated with fruit infestation rate. It could be concluded that BARI Tomato-18 and BARI Tomato-16 are resistant as well as high yielding varieties.
\end{abstract}

Keywords: Fruit borer, Resistant, Susceptible, Tomato varieties

*Corresponding author: shamimakbd.seema@gmail.com 


\section{INTRODUCTION}

Tomato (Solanum lycopersicum L.) is one of the important and remunerative vegetable crops, which is grown everywhere in the world belongs to the family Solanaceae. Bangladesh has an average yield of $13.68 \mathrm{t} \mathrm{ha}^{-1}$ and area covered was about 28130 ha (FAOSTAT, 2018). It is a rich source of vitamins, minerals and lycopene. The lycopene is a phytochemical that protects us from cancer (Mutanen et al., 2011). Tomato plants are attacked by various insects-pests however, fruit borer (Helicoverpa armigera. Hub) is the most serious one. Fruit borer larvae perforate the fruit and eats up the inner portion of the fruit. It is responsible for significant yield loss of up to 55\% (Talekar et al., 2006) and up to $46.8 \%$ in Bangladesh (Alam et al., 2007). Fruit borer damaged crop is estimated about 5 billion US dollar year ${ }^{-1}$ in the world (Sharma, 2001). It is a very hazardous pest, but the borer control operation mainly depends on chemicals which is harmful to human health. In Bangladesh tomato is grown both in summer and winter season but winter is the major tomato growing season and early November is the best time for tomato planting (Hossain et al., 1986). The average winter temperatures are around $13.9-26.5^{\circ} \mathrm{C}$, rainfall $44 \mathrm{~mm}$ and humidity $73 \%$ (BBS 2018). Tripathi and Sharma (1985) noted that temperature of $12-21^{\circ} \mathrm{C}$ is most favorable for $H$. armigera development. Due to environmental and health problems caused by pesticides (Ignacimuthu, 2007), alternative control measures that are eco-friendly and economically acceptable, should be focused. For that reason, the entomologists gave great importance to IPM (integrated pest management) program. Among the steps of IPM, usage of resistant varieties is the premier (Khanam et al., 2003).

The Lycopersicon spp. expresses resistance approximately 19 arthropod pest species of tomato (Kennedy, 2003). Sticky and toxic chemicals are released by glandular trichomes on tomato leaves result mortality of the larvae (Srinivasan and Uthamasamy, 2005). Trichome density and leaf pubescence could be a physical barrier to natural movement and development of the fruit borer (Selvanarayanan and Narayanasamy, 2006a). It is very essential to cultivate a resistant and tolerant cultivar against insect-pests especially tomato fruit borer. Therefore, it is necessary to find out borer resistant tomato varieties to avoid the use of insecticides. Therefore, this research was carried out to screen out sixteen tomato genotypes showing resistant and susceptible responses to the fruit borer, and to identify the fruit morphological characteristics influencing the infestation rate of tomato fruit borer.

\section{MATERIALS AND METHODS}

The experiment was conducted in the field of germplasm centre of Khulna University during the winter season from October 2017 to March 2018 in 1st year and October 2018 to March 2019 in the 2nd year. The average winter temperatures in $1^{\text {st }}$ year was around $13.9-26.5^{\circ} \mathrm{C}$, rainfall $44 \mathrm{~mm}$ and humidity $73 \%$ (BBS 2018) and in $2^{\text {nd }}$ year, temperature $9.9-30.7^{\circ} \mathrm{C}$, rainfall $58 \mathrm{~mm}$ and humidity $75 \%$ (BBS 2019). 


\section{Plant materials}

Sixteen tomato varieties, including 8 improved varieties viz; BARI Tomato-2, BARI Tomato-8, BARI Tomato-14, BARI Tomato-15, BARI Tomato-16, BARI Tomato17, BARI Tomato- 18 and BARI Tomato-19 developed by Bangladesh Agricultural Research Institute (BARI) and 8 available genotypes collected from the farmers in South-west Bangladesh, viz; Bonkim Ruby, Pusa Ruby, Suraksa, Patharkuchi, Ruma VF, Ruma 19, Guli and Paltola were evaluated on their performance against tomato fruit borer.

\section{Experimental Design}

The experiment was carried out in Randomized Complete Block Design (RCBD) with three replications. Total numbers of plots were 48 and plot size was $2.25 \mathrm{~m} \mathrm{x}$ $1.8 \mathrm{~m}$ consist of 15 tomato plants with spacing $45 \mathrm{~cm} \mathrm{X} 60 \mathrm{~cm}$. The experimental field was covered by the mosquito nets with the help of bamboo so the plant was protected from other insect-pests except the fruit borer because the fruit borer was artificially inoculated in the net house thus the crop was completely free from insecticidal application. Normal agronomic practices such as ploughing, manuring, irrigation and staking were conducted uniformly.

\section{Data Collections}

The twenty randomly picked fruits from each replication of each variety were harvested and measured for length and diameter with the help of digital slide caliper. Then the average was taken in $\mathrm{mm}$. The fruit shape index was recorded on the basis of the ratio of their respective fruit length and fruit diameter. The average number of fruits was recorded by counting the fruits of sample plants. The weight of thirty randomly picked fruits from each replication of each variety was measured and then the average was taken as individual fruit weight. Fruit yield (fresh and damaged) of eight randomly selected plants of each variety from the three replications recorded at each picking were cumulated and the average yield plant $^{-1}$ was worked out. Similarly, the fresh fruit was weighed and weight of fresh fruit per plant was calculated. The total number of fresh fruits and infested fruits of each variety were counted at each harvesting stage. Fruits were considered as fresh and infested based on fruit borer infestation. The number of larvae plant ${ }^{-1}$ was recorded by randomly selecting eight plants per variety in each plot. Data were recorded weekly till the infestation of fruit borer was over and the mean was calculated. \%age of fruit infestation was calculated on weight and number basis. A rating system for fruit damage developed by Kashyap and Verma (1987) was followed for estimating resistance and susceptibility of selected tomato varieties.

\section{Statistical analysis}

The data were statistically analyzed for ANOVA using STAR package computer program. Significance of differences among the treatment means was evaluated by Duncan's New Multiple Range Test (Gomez and Gomez, 1984). 


\section{RESULTS AND DISCUSSION}

The sixteen tomato varieties were significantly differed from each other in respect of fruit characters and fruit borer infestation.

\section{Fruit length (mm)}

The highest average fruit length $(60.58 \mathrm{~mm})$ was recorded in BARI Tomato-15 followed by BARI Tomato-17 $(52.00 \mathrm{~mm})$ while the minimum fruit length of $29.83 \mathrm{~h}$ mm was recorded in Ruma 19 and it was statistically at par with Guli $(31.13 \mathrm{~mm})$. Fruit length was positively non-significant co-related with fruit infestation (in 1st year $\mathrm{r}=0.214$ and in 2 nd year $\mathrm{r}=0.166$ ) (Table 1 ). On the contrary, infestation rate decreased with increasing fruit length (Daboul et al., 2011; Thakur et al., 2017).

Table 1. Fruit length fruit diameter and fruit shape index of different tomato varieties in relation to the infestation of fruit borer

\begin{tabular}{|c|c|c|c|c|c|c|c|c|c|}
\hline \multirow[t]{2}{*}{ Variety } & \multicolumn{3}{|c|}{ Fruit length $(\mathrm{mm})$} & \multicolumn{3}{|c|}{ Fruit diameter $(\mathbf{m m})$} & \multicolumn{3}{|c|}{ Fruit shape index } \\
\hline & $1^{\text {st }}$ Year & $2^{\text {nd }}$ Year & Average & $1^{\text {st }}$ Year & $2^{\text {nd }}$ Year & Average & 1st Year & $\begin{array}{l}\text { 2nd } \\
\text { Year }\end{array}$ & Average \\
\hline BARI Tomato-2 & $43.67^{\mathrm{de}}$ & $36.00^{g}$ & $39.83^{\mathrm{e}}$ & $49.67^{b-d}$ & $35.48^{\mathrm{f}-\mathrm{h}}$ & $42.57^{\text {cd }}$ & $0.89^{b-d}$ & $1.02^{\mathrm{bc}}$ & $0.96^{\mathrm{cd}}$ \\
\hline BARI Tomato-8 & $50.00^{\mathrm{bc}}$ & $39.83^{\mathrm{d}-\mathrm{f}}$ & $44.92^{\mathrm{d}}$ & $48.67^{\mathrm{b}-\mathrm{d}}$ & $38.67^{\mathrm{d}-\mathrm{f}}$ & $43.67^{\mathrm{cd}}$ & $0.73^{\mathrm{d}}$ & $0.78^{\mathrm{f}}$ & $0.75^{\mathrm{f}}$ \\
\hline BARI Tomato-14 & $65.67^{\mathrm{a}}$ & $55.50^{\mathrm{a}}$ & $60.58^{\mathrm{a}}$ & $55.00^{\mathrm{b}}$ & $45.33^{\mathrm{bc}}$ & $50.17^{b}$ & $1.03^{\mathrm{a}-\mathrm{c}}$ & $1.03^{\mathrm{bc}}$ & $1.03^{\mathrm{bc}}$ \\
\hline BARI Tomato-15 & $38.33^{\text {ef }}$ & $35.90^{\mathrm{g}}$ & $37.12^{\mathrm{e}}$ & $52.33^{\mathrm{bc}}$ & $46.00^{\mathrm{b}}$ & $49.17^{b}$ & $1.20^{\mathrm{a}}$ & $1.23^{\mathrm{a}}$ & $1.21^{\mathrm{a}}$ \\
\hline BARI Tomato-16 & $52.00^{\mathrm{bc}}$ & $43.33^{\text {cd }}$ & $47.67^{\mathrm{cd}}$ & $43.33^{\mathrm{de}}$ & $35.33^{\mathrm{f}-\mathrm{h}}$ & $39.33^{\mathrm{de}}$ & $1.20^{\mathrm{a}}$ & $1.23^{\mathrm{a}}$ & $1.21^{\mathrm{a}}$ \\
\hline BARI Tomato-17 & $55.67^{\mathrm{b}}$ & $48.33^{\mathrm{b}}$ & $52.00^{\mathrm{b}}$ & $72.67^{\mathrm{a}}$ & $62.67^{\mathrm{a}}$ & $67.67^{\mathrm{a}}$ & $0.76^{\mathrm{d}}$ & $0.77^{\mathrm{f}}$ & $0.77^{\mathrm{ef}}$ \\
\hline BARI Tomato-18 & $50.67^{\mathrm{bc}}$ & $43.83^{\mathrm{cd}}$ & $47.25^{\mathrm{cd}}$ & $44.00^{\mathrm{de}}$ & $38.67^{\mathrm{d}-\mathrm{f}}$ & $41.33^{\mathrm{ce}}$ & $1.17^{\mathrm{a}}$ & $1.13^{\mathrm{b}}$ & $1.14^{\mathrm{ab}}$ \\
\hline BARI Tomato-19 & $53.00^{\mathrm{bc}}$ & $45.82^{\mathrm{bc}}$ & $49.41^{\mathrm{bc}}$ & $41.67^{\mathrm{de}}$ & $36.88^{\mathrm{e}-\mathrm{g}}$ & $39.27^{\mathrm{de}}$ & $1.27^{\mathrm{a}}$ & $1.24^{\mathrm{a}}$ & $1.26^{\mathrm{a}}$ \\
\hline Bonkim Ruby & $43.67^{\mathrm{de}}$ & $37.67^{\mathrm{e}-\mathrm{g}}$ & $40.67^{\mathrm{e}}$ & $54.33^{\mathrm{bc}}$ & $44.67^{\mathrm{bc}}$ & $49.50^{\mathrm{b}}$ & $0.80 c^{d}$ & $0.84^{\mathrm{ef}}$ & $0.82^{\text {ef }}$ \\
\hline Pusa Ruby & $41.33^{\mathrm{ef}}$ & $36.33^{\mathrm{fg}}$ & $38.83^{\mathrm{e}}$ & $45.33^{\mathrm{cd}}$ & $38.33^{\mathrm{d}-\mathrm{g}}$ & $41.83^{d}$ & $0.91^{\mathrm{b}-\mathrm{d}}$ & $0.95^{\mathrm{cd}}$ & $0.92^{\mathrm{cd}}$ \\
\hline Suraksa & $40.33^{\mathrm{ef}}$ & $37.33^{\mathrm{e}-\mathrm{g}}$ & $38.83^{\mathrm{e}}$ & $47.00^{b-d}$ & $41.67^{\mathrm{cd}}$ & $44.33^{\mathrm{c}}$ & $0.86^{b-d}$ & $0.89^{\mathrm{de}}$ & $0.88^{\mathrm{d}-\mathrm{f}}$ \\
\hline Patharkuchi & $38.33^{\text {ef }}$ & $36.33^{\mathrm{fg}}$ & $37.67^{\mathrm{e}}$ & $37.33^{\text {ef }}$ & $34.33^{\mathrm{gh}}$ & $35.83^{\mathrm{fg}}$ & $1.05^{\mathrm{ab}}$ & $1.05^{\mathrm{bc}}$ & $1.05^{\mathrm{ab}}$ \\
\hline Ruma VF & $41.00^{\mathrm{ef}}$ & $38.67^{\mathrm{e}-\mathrm{g}}$ & $39.83^{\mathrm{e}}$ & $32.67^{\mathrm{f}}$ & $31.67^{\mathrm{i}}$ & $32.17^{\mathrm{g}}$ & $1.26^{\mathrm{a}}$ & $1.22^{\mathrm{a}}$ & $1.24^{\mathrm{a}}$ \\
\hline Ruma-19 & $29.33^{\mathrm{g}}$ & $30.33^{\mathrm{h}}$ & $29.83^{\mathrm{f}}$ & $32.33^{\mathrm{f}}$ & $34.67^{\mathrm{gh}}$ & $33.50^{\mathrm{fg}}$ & $0.91^{b-d}$ & $0.87^{\mathrm{de}}$ & $0.89^{\mathrm{de}}$ \\
\hline Guli & $35.67^{f}$ & $28.00^{\mathrm{h}}$ & $31.83^{\mathrm{f}}$ & $42.67^{\mathrm{de}}$ & $31.67^{\mathrm{i}}$ & $37.17^{\mathrm{ef}}$ & $0.84^{b-d}$ & $0.88^{\mathrm{de}}$ & $0.86^{\mathrm{d}-\mathrm{f}}$ \\
\hline Paltola & $48.67^{\mathrm{cd}}$ & $40.33^{\mathrm{de}}$ & $44.50^{\mathrm{d}}$ & $46.67^{\mathrm{cd}}$ & $39.67^{\mathrm{de}}$ & $43.17^{\mathrm{cd}}$ & $1.04^{\mathrm{a}-\mathrm{c}}$ & $1.02^{\mathrm{bc}}$ & $1.03^{\mathrm{bc}}$ \\
\hline Treatment mean & 45.50 & 39.54 & 42.52 & 46.79 & 39.54 & 43.16 & 0.9923 & 1.02 & 1.00 \\
\hline $\operatorname{LSD}(p \leq 0.01)$ & 5.84 & 3.80 & 2.97 & 8.11 & 3.82 & 4.79 & 0.2481 & 0.080 & 0.1360 \\
\hline \multicolumn{10}{|c|}{ Co-relation with fruit infestation rate } \\
\hline (r- Value) & $0.203^{\mathrm{ns}}$ & $0.166^{\mathrm{ns}}$ & $0.1783^{\mathrm{ns}}$ & $0.5170 * *$ & $0.5685^{* *}$ & $0.5674 * *$ & $-0.381 * *$ & $-0.439 * *$ & $-0.4402 * *$ \\
\hline
\end{tabular}

Means in the same column followed by same letter(s) did not differ significantly at $\mathrm{p}<0.01$ by DMRT and LSD=Least Significant Difference

\section{Fruit diameter (mm)}

The maximum fruit diameter was found in BARI Tomato-17 $(67.67 \mathrm{~mm})$, followed by BARI Tomato-14 $(50.17 \mathrm{~mm})$ and the minimum fruit diameter was recorded in Ruma-VF (32.17 mm). There was a positive and significant correlation between fruit 
diameter and per cent fruit infestation rate at 1st year, 2 nd year and average of two years $(0.5069,0.4889$ and 0.5274 respectively) (Table 1$)$. The results are in conformity with findings of Amutha and Manisegaran, (2005), Rath and Tripathy (2006), Daboul et al. (2011), Ambule et al. (2015), who also reported that increased diameter provide higher infestation. Fruit diameter may help the borer to stay on the fruit.

\section{Fruit shape index}

In case of the average of two years, the fruits of BARI Tomato-19 had the highest fruit shape index (1.26), which was statistically at par with Ruma-VF (1.24), BARI Tomato-15 (1.21) and BARI Tomato-16 (1.21). The fruits of BARI Tomato-8 recorded the lowest fruit shape index (0.75). In the present study, significantly negative correlation was found between fruit shape and fruit infestation for both the years $(\mathrm{r}=-0.38$ and -0.43 , respectively) (Table 1$)$. This is in conformity with findings of Thakur et al. (2017) and Sharma et al. (1985), who reported round shaped varieties are more susceptible than lengthen variety. The varieties with lower fruit shape index like BARI Tomato- 8 and BARI Tomato- 17 being more susceptible to fruit borer infestation on the other hand, BARI Tomato-19 with higher fruit shape index was resistant.

\section{Number of fruits plant ${ }^{-1}$}

In case of an average of the two years, the maximum amount of fruit plant ${ }^{-1}$ was found in Suraksa (53.94) and Guli (51.09). The minimum number of fruit plant $^{-1}$ was found in BARI Tomato-17 both in the first (14.61) and second (9.6) year and an average of the two years (12.11). The number of fruits plant ${ }^{-1}$ was significantly and negatively correlated with the infestation rate $(\mathrm{r}=-0.4985)$ (Table 2$)$. This finding is in a line with findings of Khanam et al. (2003) and Ambule et al. (2015). Between the two years, the number of fruit plant ${ }^{-1}$ was comparatively higher in $1^{\text {st }}$ year than that was in the $2^{\text {nd }}$ year. 
Table 2. Number of fruit plant ${ }^{-1}$ and individual fruit weight of different tomato varieties in relation to the infestation of fruit borer

\begin{tabular}{|c|c|c|c|c|c|c|}
\hline \multirow[t]{2}{*}{ Variety } & \multicolumn{3}{|c|}{ Number of fruit plant ${ }^{-1}$} & \multicolumn{3}{|c|}{ Individual fruit weight (g) } \\
\hline & $1^{\text {st }}$ Year & $2^{\text {nd }}$ Year & Average & $1^{\text {st }}$ Year & $2^{\text {nd }}$ Year & Average \\
\hline BARI Tomato-2 & $32.40^{\mathrm{g}}$ & $24.97^{\mathrm{i}}$ & $28.68^{\mathrm{g}}$ & $66.77^{\mathrm{de}}$ & $42.23^{\mathrm{f}-\mathrm{h}}$ & $54.50^{\mathrm{e}-\mathrm{ge}}$ \\
\hline BARI Tomato- 8 & $36.61^{\mathrm{fg}}$ & $28.48^{\mathrm{g}-\mathrm{i}}$ & $32.54^{\mathrm{f}}$ & $81.00^{c}$ & $50.43^{\mathrm{c}-\mathrm{f}}$ & $65.72^{c}$ \\
\hline BARI Tomato-14 & $24.99^{\mathrm{h}}$ & $25.90^{\mathrm{hi}}$ & $25.45^{\mathrm{g}}$ & $103.67^{\mathrm{b}}$ & $78.13^{\mathrm{b}}$ & $90.90^{\mathrm{b}}$ \\
\hline BARI Tomato-15 & $46.25^{\mathrm{b}-\mathrm{d}}$ & $37.17^{\mathrm{b}-\mathrm{e}}$ & $41.71^{\mathrm{d}}$ & $63.47^{\mathrm{ef}}$ & $51.43^{\mathrm{cd}}$ & $57.45^{\mathrm{d}-\mathrm{f}}$ \\
\hline BARI Tomato-16 & $49.62^{\mathrm{bc}}$ & $42.47^{\mathrm{ab}}$ & $46.05^{\mathrm{b}}$ & $61.63^{\text {ef }}$ & $47.73^{\mathrm{c}-\mathrm{f}}$ & $54.68^{\mathrm{e}-\mathrm{g}}$ \\
\hline BARI Tomato-17 & $14.61^{\mathrm{i}}$ & $9.63^{\mathrm{j}}$ & $12.11^{\mathrm{h}}$ & $129.31^{\mathrm{a}}$ & $92.27^{\mathrm{a}}$ & $110.79^{\mathrm{a}}$ \\
\hline BARI Tomato-18 & $44.65^{\mathrm{ce}}$ & $42.10^{\mathrm{a}-\mathrm{c}}$ & $43.38^{\mathrm{b}-\mathrm{d}}$ & $66.50^{\mathrm{de}}$ & $53.27^{\mathrm{cd}}$ & $59.88^{\mathrm{c}-\mathrm{e}}$ \\
\hline BARI Tomato-19 & $51.97^{\mathrm{b}}$ & $37.87^{\mathrm{b}-\mathrm{e}}$ & $44.92^{\mathrm{b}-\mathrm{d}}$ & $62.97^{\mathrm{ef}}$ & $55.63^{c}$ & $59.30^{\mathrm{ce}-\mathrm{e}}$ \\
\hline Bonkim Ruby & $39.78^{\text {ef }}$ & $29.60^{\mathrm{f}-\mathrm{i}}$ & $34.69^{\text {ef }}$ & $72.70^{\text {cd }}$ & $49.57^{\mathrm{c}-\mathrm{f}}$ & $61.13^{\mathrm{ce}}$ \\
\hline Pusa Ruby & $51.85^{\mathrm{b}}$ & $35.13^{\mathrm{d}-\mathrm{g}}$ & $43.49^{b-d}$ & $59.83^{\text {ef }}$ & $43.10^{\mathrm{e}-\mathrm{g}}$ & $51.47^{\mathrm{fg}}$ \\
\hline Suraksa & $59.41^{\mathrm{a}}$ & $48.48^{\mathrm{a}}$ & $53.94^{\mathrm{a}}$ & $54.63^{\mathrm{fg}}$ & $46.80^{\mathrm{d}-\mathrm{f}}$ & $50.72^{\mathrm{g}}$ \\
\hline Patharkuchi & $40.95^{\mathrm{d}-\mathrm{f}}$ & $32.37^{\mathrm{e}-\mathrm{g}}$ & $36.84^{\mathrm{e}}$ & $46.43^{\mathrm{gh}}$ & $34.83^{\mathrm{hi}}$ & $40.63^{\mathrm{h}}$ \\
\hline Ruma VF & $37.09^{\mathrm{fg}}$ & $35.43^{\mathrm{c}-\mathrm{f}}$ & $36.26^{\mathrm{e}}$ & $39.60^{\mathrm{h}}$ & $38.07^{\mathrm{g}-\mathrm{i}}$ & $38.83^{\mathrm{h}}$ \\
\hline Ruma 19 & $58.93^{\mathrm{a}}$ & $32.50^{\mathrm{e}-\mathrm{h}}$ & $45.71^{\mathrm{bc}}$ & $28.20^{\mathrm{i}}$ & $32.33^{\mathrm{i}}$ & $30.27^{\mathrm{i}}$ \\
\hline Guli & $61.85^{\mathrm{a}}$ & $40.33^{\mathrm{b}-\mathrm{d}}$ & $51.09^{\mathrm{a}}$ & $43.40^{\mathrm{h}}$ & $31.17^{\mathrm{i}}$ & $37.28^{\mathrm{h}}$ \\
\hline Paltola & $51.33^{\mathrm{b}}$ & $33.17^{\mathrm{e}-\mathrm{g}}$ & $42.25^{\mathrm{cd}}$ & $73.63^{\mathrm{cd}}$ & $50.80^{\mathrm{c}-\mathrm{e}}$ & $62.22^{\mathrm{cd}}$ \\
\hline Treatment mean & 43.89 & 33.49 & 38.69 & 65.86 & 49.86 & 57.85 \\
\hline $\operatorname{LSD}(p \leq 0.01)$ & 6.41 & 6.67 & 3.53 & 9.17 & 8.25 & 6.71 \\
\hline \multicolumn{7}{|c|}{ Co-relation with fruit infestation rate } \\
\hline r- Value & $-0.3996 * *$ & $-0.602 * *$ & $-0.4985 * *$ & $0.5968 * *$ & $0.4357 * *$ & $0.5450 * *$ \\
\hline
\end{tabular}

Means in the same column followed by same letter(s) did not differ significantly at $\mathrm{p}<0.01$ by DMRT and LSD=Least Significant Difference

\section{Individual fruit weight}

The highest individual fruit weight was found in BARI Tomato-17 in both the years as well as in the average $(129.31 \mathrm{~g}, 92.27 \mathrm{~g}$ and $110.79 \mathrm{~g}$ respectively) and the variety Ruma-19 showed significant minimum fruit weight $(28.20 \mathrm{~g}, 32.33 \mathrm{~g}$ and $30.27 \mathrm{~g}$ respectively) for $1^{\text {st }}$ year, $2^{\text {nd }}$ year and average. There was positive and significant correlation between individual fruit weight and $\%$ fruit infestation rate in the $1^{\text {st }}$ year, $2^{\text {nd }}$ year and an average $(0.59680,0.4357$ and 0.5450 , respectively) (Table 2). Daboul et al. (2011) observed a negative correlation between fruit weight and infestation rate that is opposed to the present result.

\section{Total fruits weight plant $^{-1}$}

The maximum weight of fruit plant $^{-1}$ (3777 g) was observed in Paltola followed by the BARI Tomato-19 (3270 g) and Suraksa (3243 g) whereas the minimum weight of fruit plant ${ }^{-1}$ was found in Ruma VF (1466 g) during the $1^{\text {st }}$ year. During the $2^{\text {nd }}$ year, the maximum weight of fruit plant $^{-1}$ was found in Suraksa (2268 g) that was statistically similar to BARI Tomato-18 (2241 g) and the minimum in BARI Tomato-17 (885 g). The two years average, weight of fruit plant ${ }^{-1}$ was significantly higher for genotype Suraksa, Paltola and BARI Tomato-19 (2755 g, and $2731 \mathrm{~g}$ and 
$2687 \mathrm{~g}$, respectively) these were statistically identical and lower for Ruma-19 (1356 g). The average yield of Tomato was comparatively higher in 1 st year $\left(2659 \mathrm{~g} \mathrm{plant}^{-1}\right)$ than that of 2nd year (1588 g plant $\left.{ }^{-1}\right)$ (Table 3). Variation of weight of fruit plant ${ }^{-1}$ was generally marked among tomato genotypes as reported earlier by Ahmad et al., 2007 and Usman et al. 2013 as influenced by biotic and abiotic factors.

Table 3. Total fruit weight plant ${ }^{-1}$ and Fresh fruit weight plant ${ }^{-1}$ of different tomato varieties in relation to the infestation of fruit borer

\begin{tabular}{|c|c|c|c|c|c|c|}
\hline \multirow[t]{2}{*}{ Variety } & \multicolumn{3}{|c|}{ 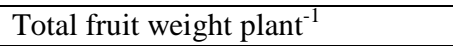 } & \multicolumn{3}{|c|}{ Fresh fruit weight plant $^{-1}$} \\
\hline & $1^{\text {st }}$ Year & $2^{\text {nd }}$ Year & Average & $1^{\text {st }}$ Year & $2^{\text {nd }}$ Year & Average \\
\hline BARI Tomato-2 & $2161^{\mathrm{e}}$ & $1054^{\mathrm{fg}}$ & $1608^{\mathrm{f}}$ & $1928.0^{\mathrm{e}-\mathrm{g}}$ & $887.19^{\mathrm{fg}}$ & $1407.65^{\text {gh }}$ \\
\hline BARI Tomato-8 & $2966^{\mathrm{b}-\mathrm{d}}$ & $1440^{\mathrm{d}-\mathrm{f}}$ & $2203^{\mathrm{de}}$ & $2330.6^{\mathrm{c}-\mathrm{e}}$ & $1070.67^{\mathrm{e}-\mathrm{g}}$ & $1701.00^{\mathrm{fg}}$ \\
\hline BARI Tomato-14 & $2587^{\mathrm{d}}$ & $202^{\mathrm{ab}}$ & $2304^{\text {cd }}$ & $2107.0^{\mathrm{d}-\mathrm{f}}$ & $1686.0^{\mathrm{bc}}$ & $1896.33^{\mathrm{d}-\mathrm{f}}$ \\
\hline BARI Tomato-15 & $2929^{b-d}$ & $1910^{\mathrm{a}-\mathrm{c}}$ & $2419^{b-d}$ & $2347.33^{\mathrm{c}-\mathrm{d}}$ & $1554.67^{\mathrm{b}-\mathrm{d}}$ & $1951.00^{\mathrm{d}-\mathrm{f}}$ \\
\hline BARI Tomato-16 & $3057^{\mathrm{b}-\mathrm{c}}$ & $2029^{\mathrm{ab}}$ & $2543^{\mathrm{a}-\mathrm{c}}$ & $2967.25^{\mathrm{ab}}$ & $1938.61^{\mathrm{ab}}$ & $2452.94^{\mathrm{ab}}$ \\
\hline BARI Tomato-17 & $1890^{\mathrm{ef}}$ & $885^{\mathrm{g}}$ & $1388^{\mathrm{f}}$ & $1561.51^{\mathrm{gh}}$ & $662.52^{\mathrm{g}}$ & $1112.02^{\mathrm{h}}$ \\
\hline BARI Tomato-18 & $2965^{\text {bd }}$ & $2241^{\mathrm{a}}$ & $2603^{\mathrm{ab}}$ & $2876.44^{\mathrm{ab}}$ & $2149.09^{\mathrm{a}}$ & $2512.77^{\mathrm{a}}$ \\
\hline BARI Tomato-19 & $3270^{\mathrm{b}}$ & $2105^{\mathrm{ab}}$ & $2687^{\mathrm{a}}$ & $2993.33^{\mathrm{a}}$ & $1854.19^{\mathrm{ab}}$ & $2423.70^{\mathrm{ab}}$ \\
\hline Bonkim Ruby & $2891^{\mathrm{b}-\mathrm{d}}$ & $1469^{\mathrm{d}-\mathrm{f}}$ & $2180^{\mathrm{de}}$ & $2650.07^{\mathrm{a}-\mathrm{c}}$ & $1299.46^{c-f}$ & $1974.77^{\mathrm{d}-\mathrm{f}}$ \\
\hline Pusa Ruby & $3092^{\mathrm{bc}}$ & $1515^{\mathrm{c}-\mathrm{e}}$ & $2304^{\text {cd }}$ & $2907.77^{\mathrm{ab}}$ & $1392.41^{\mathrm{c}-\mathrm{e}}$ & $2150.0^{\mathrm{b}-\mathrm{d}}$ \\
\hline Suraksa & $3243^{\mathrm{b}}$ & $2268^{\mathrm{a}}$ & $2755^{\mathrm{a}}$ & $2962.50^{\mathrm{ab}}$ & $1990.56^{\mathrm{ab}}$ & $2476.53^{\mathrm{a}}$ \\
\hline Patharkuchi & $1901^{\mathrm{ef}}$ & $1139^{\mathrm{e}-\mathrm{g}}$ & $1520^{\mathrm{f}}$ & $1739.74^{\text {f-h }}$ & $1016.44^{\mathrm{e}-\mathrm{g}}$ & $1377.67^{\mathrm{h}}$ \\
\hline Ruma VF & $1466^{\mathrm{g}}$ & $1350^{\mathrm{d}-\mathrm{f}}$ & $1408^{\mathrm{f}}$ & $1406.26^{\mathrm{h}}$ & $1275.86^{\mathrm{c}-\mathrm{f}}$ & $1341.06^{\mathrm{h}}$ \\
\hline Ruma 19 & $1662^{\text {fg }}$ & $1050^{\mathrm{fg}}$ & $1356^{\mathrm{f}}$ & $1494.50^{\mathrm{g}-\mathrm{h}}$ & $897.03^{f-g}$ & $1195.77^{\mathrm{h}}$ \\
\hline Guli & $2682^{\text {cd }}$ & $1256^{\mathrm{d}-\mathrm{g}}$ & $1969^{e}$ & $2495.62^{\mathrm{b}-\mathrm{d}}$ & $1153.31^{\mathrm{d}-\mathrm{f}}$ & $1824.33^{\text {ef }}$ \\
\hline Paltola & $3777^{\mathrm{a}}$ & $1685^{\mathrm{b}-\mathrm{d}}$ & $2731^{\mathrm{a}}$ & $3057.67^{\mathrm{a}}$ & $1175.00^{\mathrm{d}-\mathrm{f}}$ & $2116.67^{\mathrm{c}-\mathrm{e}}$ \\
\hline Treatment mean & 2659 & 1588 & 2124 & 2364.12 & 1375.21 & 1869.65 \\
\hline $\operatorname{LSD}(p \leq 0.01)$ & 417 & 431 & 264 & 496 & 450 & 319 \\
\hline \multicolumn{7}{|c|}{ Co-relation with fruit infestation rate } \\
\hline r-Value & $0.1731 \mathrm{n}$ & $-0.289 *$ & $-0.010 \mathrm{~ns}$ & $-0.124 \mathrm{~ns}$ & $-0.532 * *$ & $-0.3207 *$ \\
\hline
\end{tabular}

Means in the same column followed by same letter(s) did not differ significantly at $\mathrm{p}<0.01$ by DMRT and LSD=Least Significant Difference

\section{Fresh fruit weight plant ${ }^{-1}$}

Fresh fruit means the fruit are not infested by fruit borer, the fresh fruit were separated and weighted. In $1^{\text {st }}$ year, the variety Paltola, BARI Tomato-19, BARI Tomato-16, Suraksa and Pusha Ruby gave the significantly higher fresh fruit weight of $3057.67 \mathrm{~g}$ plant $^{-1}, 2993.33 \mathrm{~g} \mathrm{plant}^{-1}, 2967.2 \mathrm{~g} \mathrm{plant}^{-1}, 2962.50 \mathrm{~g} \mathrm{plant}^{-1}$ and $2907.77 \mathrm{~g} \mathrm{plant}^{-1}$ respectively, while Ruma VF gave significantly lower fresh fruit yield plant ${ }^{-1}$ of $1406.26 \mathrm{~g} \mathrm{plant}^{-1}$. In the $2^{\text {nd }}$ year, significantly higher fresh yield was obtained from the genotype BARI Tomato-18, BARI Tomato-16, BARI Tomato-19 and Suraksa (2149.09 $\mathrm{g}$ plant ${ }^{-1}, 1938.61 \mathrm{~g} \mathrm{plant}^{-1}, 1854.19 \mathrm{~g} \mathrm{plant}^{-1}$ and $1990.56 \mathrm{~g}$ plant $^{-1}$ respectively), whereas lower was observed in genotype BARI Tomato-17 $662.52 \mathrm{~g} \mathrm{plant}^{-1}$. The mean fresh yield for the two years was significantly higher for genotype BARI Tomato-18 $\left(2512.77 \mathrm{~g} \mathrm{plant}^{-1}\right)$ and Suraksa (2476.53 $\left.\mathrm{g} \mathrm{plant}^{-1}\right)$ and lower for BARI Tomato-17 (1112.02 $\left.\mathrm{g} \mathrm{plant}^{-1}\right)$ (Table 3). The observed variation in fresh yield among the tested 
variety, may be due to the response of their genotypes to tomato fruit borer attack. Fresh yield was negatively correlated with fruit infestation in both $1^{\text {st }}$ and $2^{\text {nd }}$ year $(\mathrm{r}=-$ $0.124 \mathrm{~ns}$ and -0.532 , respectively) that means the genotypes with lower infestation provide higher yields (Table 3). Genotype BARI Tomato-18 and Suraksa had less fruit infestation and gave maximum fresh yield, while BARI Tomato-17 yielded minimum because of high fruit infestation. Similar results were also reported by Ashfaq et al., 2012 and Usman et al., 2013, who showed that resistant genotypes show higher yield than susceptible genotypes against the fruit borer.

\section{Number of fruit borer larvae plant ${ }^{-1}$}

The observed fruit borer larval population plant $^{-1}$ on different tomato genotypes are given in Table 4. On average, of two years data, the highest number of larval population plant ${ }^{-1}$ was found in the paltola (2.57 larvae) and that was the minimum on genotypes BARI Tomato-18 (0.31 larvae) and Ruma VF (0.38 larvae). Correlation between larvae of borer plant ${ }^{-1}$ and fruit infestation was highly significantly positive for both the years as well as mean for the two years $(r=0.749$, 0.767 and 0.789 , respectively). This type of findings was also reported by several researchers (Sajjad et al., 2011; Ashfaq et al., 2012; Usman et al., 2013; Ambule et al. 2015; Thakur et al., 2017; Amin et al., 2017).

Table 4. Fruit borer larvae plant ${ }^{-1}$ and $\%$ fruit weight loss of different tomato varieties in relation to the infestation of fruit borer

\begin{tabular}{|c|c|c|c|c|c|c|}
\hline \multirow[t]{2}{*}{ Variety } & \multicolumn{3}{|c|}{ Fruit borer larvae plant ${ }^{-1}$} & \multicolumn{3}{|c|}{$\%$ weight of infested fruit } \\
\hline & $1^{\text {st }}$ Year & $2^{\text {nd }}$ Year & Average & $1^{\text {st }}$ Year & $2^{\text {nd }}$ Year & Average \\
\hline BARI Tomato-2 & $0.66^{\mathrm{de}}$ & $1.11^{\mathrm{d}-\mathrm{g}}$ & $0.88^{\mathrm{d}-\mathrm{g}}$ & $10.78^{\mathrm{b}-\mathrm{e}}$ & $15.84^{\mathrm{b}-\mathrm{d}}$ & $13.30^{\mathrm{b}-\mathrm{e}}$ \\
\hline BARI Tomato-8 & $1.85^{\mathrm{b}}$ & $2.50^{\mathrm{ab}}$ & $2.18^{\mathrm{ab}}$ & $21.57^{\mathrm{a}}$ & $25.70^{\mathrm{ab}}$ & $23.63^{\mathrm{a}}$ \\
\hline BARI Tomato-14 & $0.98^{\mathrm{cd}}$ & $1.34^{\mathrm{c}-\mathrm{e}}$ & $1.17^{\mathrm{ce}}$ & $18.55^{\mathrm{a}-\mathrm{c}}$ & $16.65^{\mathrm{bc}}$ & $17.57^{\mathrm{a}-\mathrm{d}}$ \\
\hline BARI Tomato-15 & $1.54^{\mathrm{bc}}$ & $1.83^{b c}$ & $1.69^{\mathrm{bc}}$ & $19.81^{\mathrm{ab}}$ & $18.58^{\mathrm{bc}}$ & $19.20^{\mathrm{a}-\mathrm{c}}$ \\
\hline BARI Tomato-16 & $0.28^{\mathrm{e}}$ & $0.51^{\mathrm{f}-\mathrm{h}}$ & $0.40^{\mathrm{fg}}$ & $2.92^{\mathrm{e}}$ & $4.45^{\mathrm{e}}$ & $3.63^{\mathrm{fg}}$ \\
\hline BARI Tomato-17 & $0.46^{\mathrm{de}}$ & $0.71^{\mathrm{e}-\mathrm{h}}$ & $0.59^{e-g}$ & $17.46^{\mathrm{a}-\mathrm{d}}$ & $25.22^{\mathrm{ab}}$ & $21.33^{\mathrm{ab}}$ \\
\hline BARI Tomato-18 & $0.23^{\mathrm{e}}$ & $0.38^{\mathrm{h}}$ & $0.31^{\mathrm{g}}$ & 2.97 & $4.20^{\mathrm{e}}$ & $3.57^{\mathrm{g}}$ \\
\hline BARI Tomato-19 & $0.77^{\mathrm{de}}$ & $1.09^{\mathrm{d}-\mathrm{g}}$ & $0.93^{\mathrm{d}-\mathrm{f}}$ & $8.45^{\mathrm{de}}$ & $11.98^{\mathrm{c}-\mathrm{e}}$ & $10.23^{\mathrm{d}-\mathrm{g}}$ \\
\hline Bonkim Ruby & $0.55^{\mathrm{de}}$ & $0.85^{\mathrm{d}-\mathrm{h}}$ & $0.70^{\mathrm{d}-\mathrm{g}}$ & $8.34^{\mathrm{de}}$ & $11.75^{\mathrm{c}-\mathrm{e}}$ & $10.03^{\mathrm{d}-\mathrm{g}}$ \\
\hline Pusa Ruby & $0.54^{\mathrm{de}}$ & $0.79^{\mathrm{d}-\mathrm{h}}$ & $0.67^{\mathrm{d}-\mathrm{g}}$ & $5.99^{e}$ & $8.32^{\mathrm{c}-\mathrm{e}}$ & $7.17^{\mathrm{e}-\mathrm{g}}$ \\
\hline Suraksa & $1.00^{\mathrm{cd}}$ & $1.45^{\mathrm{cd}}$ & $1.23^{\mathrm{cd}}$ & $8.65^{\mathrm{de}}$ & $12.31^{\mathrm{c}-\mathrm{e}}$ & $10.50^{\mathrm{d}-\mathrm{g}}$ \\
\hline Patharkuchi & $0.69^{\mathrm{de}}$ & $1.07^{\mathrm{d}-\mathrm{h}}$ & $0.89^{\mathrm{d}-\mathrm{g}}$ & $8.58^{\mathrm{de}}$ & $10.64^{\mathrm{c}-\mathrm{e}}$ & $9.63^{\mathrm{d}-\mathrm{g}}$ \\
\hline Ruma VF & $0.27^{\mathrm{e}}$ & $0.48^{\text {gh }}$ & $0.38^{\mathrm{fg}}$ & $4.04^{\mathrm{e}}$ & $5.68^{\mathrm{de}}$ & $4.83^{\mathrm{e}-\mathrm{g}}$ \\
\hline Ruma 19 & $0.96^{\mathrm{d}}$ & $1.19^{\mathrm{c}-\mathrm{f}}$ & $1.08^{\mathrm{de}}$ & $10.05^{\mathrm{c}-\mathrm{e}}$ & $14.42^{\mathrm{c}-\mathrm{e}}$ & $12.23^{\mathrm{c}-\mathrm{f}}$ \\
\hline Guli & $0.60^{\mathrm{de}}$ & $0.85^{\mathrm{d}-\mathrm{h}}$ & $0.73^{\mathrm{d}-\mathrm{g}}$ & $6.97 \mathrm{e}$ & $8.39^{\mathrm{c}-\mathrm{e}}$ & $7.67^{\mathrm{e}-\mathrm{g}}$ \\
\hline Paltola & $2.58^{\mathrm{a}}$ & $2.56^{\mathrm{a}}$ & $2.57^{\mathrm{a}}$ & $19.04^{\mathrm{a}-\mathrm{c}}$ & $30.74^{\mathrm{a}}$ & $24.90^{\mathrm{a}}$ \\
\hline Treatment mean & $0.87^{\mathrm{b}}$ & $1.17 \mathrm{a}$ & 1.02 & $10.89^{\mathrm{b}}$ & 14.04 & 12.46 \\
\hline $\operatorname{LSD}(p \leq 0.01)$ & 0.57 & 0.70 & 0.58 & 9.74 & 10.47 & 8.63 \\
\hline \multicolumn{7}{|c|}{ Co-relation with fruit infestation rate } \\
\hline r-Value & $0.749 * *$ & $0.767 * *$ & $0.789 * *$ & $0.9148 * *$ & $0.981 * *$ & $0.971 * *$ \\
\hline
\end{tabular}

Means in the same column followed by same letter(s) did not differ significantly at $\mathrm{p}<0.01$ by DMRT and LSD=Least Significant Difference 


\section{Percent weight loss}

The data presented in Table 4 revealed that the average performance for two years showed, the significantly identical lowest fruit weight loss was found in BARI Tomato-18 (3.57\%), BARI Tomato-16 (3.63\%) and Ruma VF (4.83\%). The highest fruit weight loss was found in genotypes Paltola (24.90\%), BARI Tomato-8 (23.63\%) and BARI Tomato-17 (21.33\%). Highly significant positive correlation was observed between \% yield loss and fruit infestation for both $1^{\text {st }}$ year $(r=0.9148)$ and $2^{\text {nd }}$ year $(r=0.981)$ and means for the two years $(r=0.971)$. The findings of the present study are in accordance with Usman et al. (2013), Amin et al. (2017), who reported that higher infestation provides higher \% fruit weight loss.

\section{Percent of infested fruit}

Infestation due to fruit borer among different varieties varied significantly. The minimum number of infested fruits was recorded for BARI Tomato-16 and BARI Tomato-18 while the maximum amount of fruit damage was found in BARI Tomato- 8 and Paltola for both the years and ultimately the average (Table 5). Clissold et al. (2006) indicated that feeding of early larval instars obstructed by tough leaves.

Table 5. Rank on two years mean infested fruit (\%), and Rating on resistance of sixteen tomato varieties

\begin{tabular}{|c|c|c|c|c|c|}
\hline \multirow{3}{*}{ Variety } & \multicolumn{3}{|c|}{$\%$ Infested Fruit } & \multirow{3}{*}{ Rank } & \multirow{3}{*}{ Rating } \\
\hline & \multicolumn{2}{|c|}{ Years } & \multirow{2}{*}{ Average } & & \\
\hline & 2018 & 2019 & & & \\
\hline BARI Tomato-2 & $13.25^{\mathrm{d}-\mathrm{f}}$ & $20.04^{\mathrm{b}}$ & $16.65^{\mathrm{c}-\mathrm{e}}$ & 11 & Moderately resistant \\
\hline BARI Tomato- 8 & $27.13^{\mathrm{a}}$ & $32.30^{\mathrm{a}}$ & $29.71^{\mathrm{a}}$ & 16 & Moderately susceptible \\
\hline BARI Tomato-14 & $17.48^{\mathrm{c}-\mathrm{e}}$ & $20.09^{b}$ & $18.79^{\mathrm{cd}}$ & 12 & Moderately susceptible \\
\hline BARI Tomato-15 & $18.17^{\mathrm{cd}}$ & $20.82^{\mathrm{b}}$ & $19.50^{\mathrm{bc}}$ & 13 & Moderately resistant \\
\hline BARI Tomato-16 & $3.51^{\mathrm{i}}$ & $5.19^{\mathrm{e}}$ & $4.36^{\mathrm{h}}$ & 2 & Resistant \\
\hline BARI Tomato-17 & $21.40^{\mathrm{bc}}$ & $30.60^{\mathrm{a}}$ & $26.01^{\mathrm{ab}}$ & 14 & Moderately susceptible \\
\hline BARI Tomato-18 & $3.57^{\mathrm{i}}$ & $5.01^{\mathrm{e}}$ & $4.30^{\mathrm{h}}$ & 1 & Resistant \\
\hline BARI Tomato-19 & $10.40^{\mathrm{f}-\mathrm{h}}$ & $14.61^{\mathrm{b}-\mathrm{d}}$ & $12.51^{\mathrm{d}-\mathrm{f}}$ & 8 & Moderately resistant \\
\hline Bonkim Ruby & $10.10^{\mathrm{f}-\mathrm{h}}$ & $14.11^{\mathrm{b}-\mathrm{e}}$ & $12.11^{\mathrm{e}-\mathrm{g}}$ & 7 & Moderately resistant \\
\hline Pusa Ruby & $7.11^{\mathrm{g}-\mathrm{i}}$ & $9.93^{\mathrm{c}-\mathrm{e}}$ & $8.53^{\mathrm{f}-\mathrm{h}}$ & 4 & Resistant \\
\hline Suraksa & $10.53^{\mathrm{fg}}$ & $14.84^{\mathrm{b}-\mathrm{d}}$ & $12.69^{\mathrm{d}-\mathrm{f}}$ & 9 & Moderately resistant \\
\hline Patharkuchi & $8.20^{\mathrm{f}-\mathrm{i}}$ & $13.15^{\mathrm{b}-\mathrm{e}}$ & $10.68^{\mathrm{e}-\mathrm{h}}$ & 6 & Moderately resistant \\
\hline Ruma VF & $4.89^{\mathrm{hi}}$ & $6.79^{\mathrm{de}}$ & $5.85^{\mathrm{gh}}$ & 3 & Resistant \\
\hline Ruma 19 & $12.29^{\mathrm{e}-\mathrm{g}}$ & $17.75^{\mathrm{bc}}$ & $15.03^{\mathrm{c}-\mathrm{f}}$ & 10 & Moderately resistant \\
\hline Guli & $8.46^{\mathrm{f}-\mathrm{i}}$ & $9.37^{\mathrm{c}-\mathrm{e}}$ & $8.92^{\mathrm{f}-\mathrm{h}}$ & 5 & Resistant \\
\hline Paltola & $24.99^{\mathrm{ab}}$ & $32.92^{\mathrm{a}}$ & $28.95^{\mathrm{a}}$ & 15 & Moderately susceptible \\
\hline Treatment mean & 12.60 & 16.72 & 14.66 & & \\
\hline $\operatorname{LSD}(p \leq 0.01)$ & 5.57 & 9.4 & 6.58 & & \\
\hline
\end{tabular}

Means in the same column followed by same letter(s) did not differ significantly at $\mathrm{p}<0.01$ by DMRT and LSD=Least Significant Difference 
Antibiotic effects of phenols and acidity of tomato fruits are also achieved to the host plant resistance against tomato fruit borer (Kashyap and Verma, 1987; Banerjee and Kallo, 1989; Selvanarayanan and Narayanasamy, 2006 a). BARI Tomato-16, BARI Tomato-18, Pusa Ruby, Ruma VF and Guliwere found to be a resistant having infestation less than 10\% and BARI Tomato-2, BARI Tomato-15, BARI Tomato-19, Bonkim Ruby, Suraksa, Patharkuchi and Ruma 19 were found to moderately resistant with infestation rates falling between 10 to $20 \%$. BARI Tomato-8, BARI Tomato-14, BARI Tomato-17, and Paltola were moderately susceptible with 20.1 to $30.0 \%$ fruit damage (Table 5). Among the sixteen varieties, none of the tested varieties were completely resistant to the attack of fruit borer. The results of the present study were supported by the researchers (Khanam et al., 2003; Selvanarayanan and Narayanasamy, 2006b; Sajjad et al., 2011; Usman et al., 2013; Ambule et al., 2015; Amin et al., 2017; Thakur et al., 2017).

\section{CONCLUSION}

It can be concluded that none of the tested genotypes were free from $H$. armigera infestation. BARI Tomato-18 and BARI Tomato-16 gave better results as borer resistance with higher fruit shape index and fresh yield plant ${ }^{-1}$. BARI Tomato-8, BARI Tomato-17 and Paltola was more susceptible containing higher infestation as well as higher \% yield loss by fruit borer. BARI Tomato-18 and BARI Tomato-16 may be included in IPM system.

\section{ACKNOWLEDGEMENTS}

The authors are grateful to the Bangobondhu Fellowship Trust for financial support to conduct the study.

\section{REFERENCES}

Ahmad, F., Khan, O., Sarwar, S., Hussain, A. and Ahmad, S. (2007). Performance and evaluation of tomato cultivars at high altitude. Sarhad Journal of Agriculture, 23:581-585.

Alam, S.N., Rahman, A.K.M.Z. and Dutta, N.K. (2007). Annual report 2006-2007. Division of Entomology, BARI, Gazipur-1701. Pp.163.

Ambule, A.T., Radadia, G.G., Patil, D.L. and Toke, N.R. (2015). Morphological characters of tomato in relation to resistance against tomato fruit borer, Helicoverpaarmigera (hubner). International Journal of Plant Protection, 8(1):152-156.

Amin, M., Chakma, A., Alam, M., Hossain, M. and G.F. (2017). Screening of tomato varieties against tomato fruit borer and associated plant characters. SAARC Journal of Agriculture, 14(2):150-161. 
Amutha, M. and Manisegaran, S. (2005). Biophysical basis of resistance in certain promising tomato accessions against tomato fruit borer Helicoverpaarmigera (Hubner). Indian Journal of Entomology, 67(2):155161.

Ashfaq, M., Sajjad, M., Ane, M.N.U. and Rana, N. (2012). Morphological and chemical characteristics of tomato foliage as mechanisms of resistance to Helicoverpaarmigera (Hubner) (Lepidoptera: Noctuidae) larvae. African Journal of Biotechnology, 11:7744-7750.

Banerjee, M.K. and Kalloo, G. (1989). Role of phenols in resistant to tomato leaf curl virus, Fusarium wilt and fruit borer in Lycopersicon. Current Science, 58:575-576.

Bangladesh Bureau of Statistics (BBS). (2018). Statistics and Informatics Division (SID), Ministry of Planning, Chapter II, Environment and Disaster. Pp. 5.

Bangladesh Bureau of Statistics (BBS). (2019). Statistics and Informatics Division (SID), Ministry of Planning, Chapter II, Environment and Disaster. Pp. 5.

Clissold, F., Sanson, G.D. and Read, J., (2006). The paradoxical effects of nutrient ratios and supply rates on an out breaking insect herbivore, the Australian plague locust. Journal of Animal Ecology, 75:1000-1013.

Daboul, Y.S., Bsheer, M.N. and Baseet, Y.I. (2011). Relative susceptibility of some tomato cultivars to Helicoverpa armigera (Hubner) (Lepidoptera: Noctuidae) infestation in Dara'a- Syria. Jordan Journal of Agricultural Science, 7(4):617-623.

FAOSTAT. (2018). Yield world statistics and data. www.faostat/en/\#dataQC. Accessed on $16^{\text {th }}$ February, 2020.

Gomez, K.A. and Gomez, A.A. (1984). Statistical procedures for agricultural research. Second edition. Wiley, J., Sons. A Wiley international Publication. New York. Pp. 680.

Hossain, M.M., Karim, A.M., Haque, M., Haque, M.M. and Hossain, A.K.M.A. (1986). Performance of some tomato lines planted at different dates. Bangladesh Horticulture, 1(1):25-28.

Ignacimuthu, S. (2007). Insect pest management; meeting report. Current Science, 92:1336-1337.

Kashyap, R.K. and Verma, A.N. (1986). Screening of tomato genotypes for susceptibility to fruit borer, Heliothisarmigera (Hubner). Indian Journal of Entomology, 48:46-53

Kennedy, G. (2003). Tomato, pests, parasitoids and predators: Tritrophic Interactions Involving the Genus Lycopersicon. Annul Review of Entomology, 48:51-72. 
Khanam, U.K.S., Hossain, M., Ahmed, N., Uddin, M.M. and Hossain M.S. (2003). Varietal screening of tomato to tomato fruit borer, Helicoverpa armigera (Hub.) and associated tomato plant characters. Pakistan Journal of Biological Science, 6:413-412.

Levy, J., Walfisch, S., Atzmon, A., Hirsch, K., Khanin, M., Linnewiel, K., Morag, Y., Salman, H., Veprik, A., Danilenko, M. and Sharoni, Y. (2011). The role of tomato lycopene in cancer prevention. In: Vegetables, whole grains, and their derivatives in Cancer Prevention. Springer, Netherlands. Volume 2. Pp. 47-66.

Rath, L.K. and Tripathy, J.B. (2006). Non-preference mechanism of resistance in some selected tomato varieties to tomato fruit borer Helicoverpa armigera (Hubner). Indian Journal of Entomology, 68(4):325-328.

Sajjad, M., Ashfaq, M., Suhail, A. and Akhtar, S. (2011). Screening of tomato genotypes for resistance to tomato fruit borer (Helicoverpa armiger Hubner) in Pakistan. Pakistan Journal of Agricultural Sciences, 48:59-62

Selvanarayanan, V. and Narayanasamy, P. (2006a). Factors of resistance in tomato accessions against the fruit worm, Helicoverpa armigera (Hubner). Crop Protection, 25:1075-1079

Selvanarayanan, V. and Narayanasamy, P. (2006b). Assessment of tomato germplasm for resistance to fruit borer Helicoverpa armigera Hubner. Journal of Vegetation Science, 12:71-79.

Sharma, H.C. (2001). Cotton bollworm/legume pod borer, Helicoverpa armigera (Hubner) (Noctuidae: Lepidoptera), Biology and management. Crop Protect Compendium. CAB International, Wallingford. Pp. 70.

Sharma, N.K., Dhankar, B.S. and Pandita, M.L. (1985). Interrelationship and path analysis studies for yield and susceptibility to shoot and fruit borer components in brinjal Harayana. Journal of Horticultural Science, 14:114-117.

Srinivasan, R. and Uthamasamy, S. (2005). Trichome density and antibiosis affect resistance of tomato to fruit borer and whitefly under laboratory conditions. Journal of Vegetable Science, 11(2):3-17.

Talekar, N.S., Open, R.T. and Hanson, P. (2006). Helicoverpa armigera management: a review of AVRDC's research on host plant resistance in tomato. Crop Protection, 5:461-467.

Thakur, P., Rana, R.S. and Kumar, A. (2017). Biophysical characters of tomato varieties in relation to resistance against tomato fruit borer, Helicoverpa armigera (Hubner). Journal of Entomology and Zoology Studies, 108(56): 108-112. 
Tripathi, S.R. and Sharma, S.K. (1985). Population dynamics of Helicoverpa armigera (Hub.) on gram in the Terai belt of NEUP. GiarnaleItaliana di Entomologia, 2(10):347-352.

Usman, A., Khan, I.A., Inayatullah, M., Saljoqi, A.U.R. and Shah, M. (2013). Appraisal of Different Tomato Genotypes against Tomato Fruit Worm (Helicoverpaarmigera Hub.) Infestation. Pakistan Journal of Zoology, 45(1):113-119. 